\title{
KIMA, PERLUKAH MENUNGGU F2 UNTUK PERDAGANGAN? SUATU KAJIAN BERDASARKAN MARKER GENETIK
}

\author{
Estu Nugroho*) dan Maria Goretti Lily Panggabean*) \\ *) Balai Riset Perikanan Budidaya Air Tawar, Bogor \\ *) Pusat Oceanografi- LIPI
}

\begin{abstract}
ABSTRAK
Kima (Tridagnidae) merupakan salah satu komoditas air laut yang prospektif secara ekonomis, tercatat harga di Taiwan adalah \$35--\$142 per kg. Dalam pengembangan akuabisnis kima masih dijumpai kendala di antaranya adalah adanya aturan bahwa hanya turunan kedua atau F2 yang boleh diperdagangkan karena masuk dalam daftar CITES (Convention on Trade of Endangered Species) menurut PP No. 8 tahun 1999 tentang pemanfaatan satwa. Karena pertumbuhannya yang relatif lambat serta adanya negara lain, misalnya Filipina, Fiji, dan Tai wan yang memperdagangkan hasil budidaya pada turunan F1, maka keadaan ini sangat merugikan pihak Indonesia. Kajian tentang permasalahan penurunan variasi genetik merupakan salah satu alternatif untuk mendukung adanya pelonggaran persyaratan perdagangan kima tersebut. Kajian genetika dengan menggunakan marker genetik menunjukkan bahwatidak terjadi penurunan variasi genetik seperti yang dikuatirkan sebelumnya. Keragaman genetik pada F1 meningkat dibandingkan dengan induknya, yaitu 0,073 dan 0,023 . Jarak genetik antar populasi yang diuji adalah sebesar 0,016.
\end{abstract}

\section{KATA KUNCl: kima, perdagangan, marker genetik}

\section{PENDAHULUAN}

Di dunia, terdapat 9 jenis kima (Tridagnidae) yang telah diketahui menurut Rosewater (1965; 1982). Tujuh jenis di antaranya yaitu Tridagna gigas, T. derasa, T. squamosa, T. maxima, T. crocea, Hippopus hippopus, dan $\mathrm{H}$. porcellanus merupakan penghuni ekosistem terumbu karang di Indonesia (Gambar 1).

Sumber daya kima telah mengalami tekanan eksploitasi berlebihan, terutama di perairan Indonesia bagian barat, khususnya untuk jenis kima yang besar seperti T. gigas dan T. derasa. Kima banyak dicari karena nilai otot adduktornya yang tinggi (\$35--\$142/kg) untuk dikonsumsi di pasaran Hongkong dan Taiwan. Besar kemungkinan kima raksasa tersebut dicuri oleh kapal-kapal asing seperti yang terjadi di perairan Indonesia (Pearson, 1977). Karena keberadaannya yang terancam punah tersebut, kima telah dikategorikan sebagai binatang yang dilindungi (Wells et al., 1983), sehingga para ilmuwan kemudian mengembangkan teknologi budidaya kima (Panggabean, 1987).

Budidaya kima semula ditujukan untuk restocking atau pemulihan sumberdayanya. Di samping untuk tujuan konservasi tersebut, budidaya kima juga dapat ditingkatkan untuk tujuan komersial sehingga dapat memberikan keuntungan yang memadai. Di negara-negara Indo-Pasifik, budidaya kima telah mengalami surplus dan berkembang menjadi usaha domestikasi untuk komoditas ikan hias bagi para hobiis. Peraturan negara-negara tersebut telah mengijinkan perdagangan kima hasil budidaya.

Sedangkan Indonesia yang meratifikasi peraturan CITES hanya mengijinkan perdagangan kima untuk generasi kedua (F2) hasil budidaya. Hal ini sangat merugikan karena tidak menarik minat penanam modal untuk mengembangkan budidaya kima. Padahal kima sebagai hewan langka ternyata mempunyai fekunditas yang sangat tinggi yaitu puluhan hingga ratusan juta telur yang akan mempengaruhi nilai keragaman genetik yang dimilikinya.

Dalam rangka menunjang upaya pengembangan budidaya kima tersebut, maka diperlukan informasi genetik dari generasi pertama untuk menjawab persoalan dugaan adanya penurunan tingkat keragaman atau keragaman genetik sehingga akan berbahaya bagi populasinya jika diperdagangkan pada tahapan tersebut. Keragaman genetik merupakan informasi penting yang dapat digunakan untuk mengevaluasi fitness individu (jangka pendek) dan kelangsungan hidup dari suatu populasi (jangka panjang) (Ferguson et al., 1995).

\section{AMPLIFIKASI DAERAH CYTOCHROME I}

Kima dari jenis Hippopus hippopus hasil budidaya dari daerah Bali digunakan sebagai kelompok sampel yang 

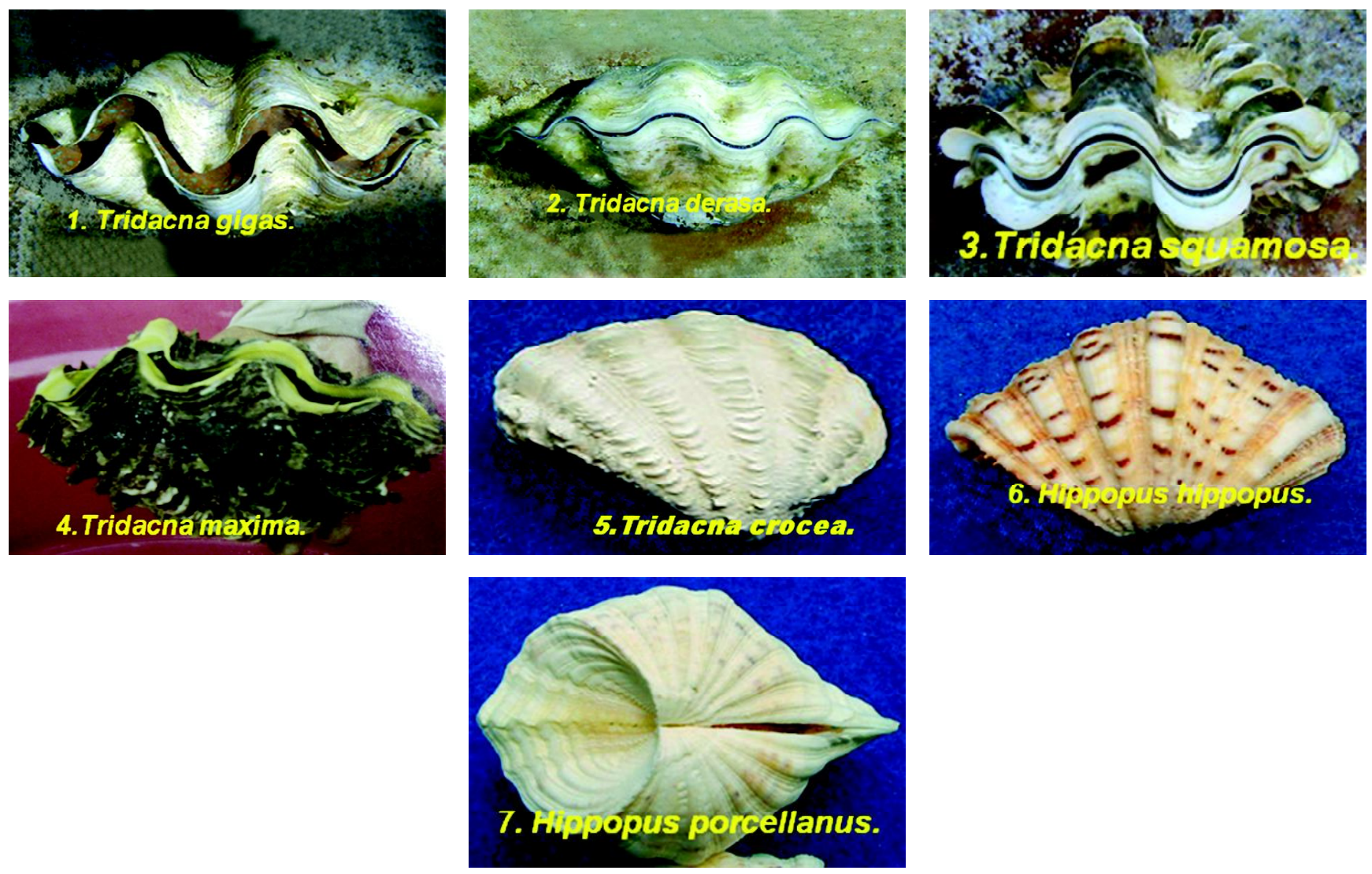

Gambar 1. Tujuh jenis kima yang terdapat di Indonesia

dianalisis secara molekuler DNA. DNA kima diekstraksi dari potongan otot adduktor untuk kima induk dan sebagian daging untuk kima anak hasil turunan pertama (F1) dengan menggunakan metode Phenol-Chloroform.

Daerah Cytochrome I diamplifikasi dengan metode Polymerase Chain Reaction (PCR). Adapun primer yang digunakan untuk mengamplifikasi sekuens Cytochrome I adalah primer LH 1509 (CAT ATT AAA CCC GAA TGA TAT TT) dan primer FH 1202 (ATA ATA GGG TAT CTA ATC CTA GTT T).

Komposisi reaksi yang digunakan dalam amplifikasi terdiri atas: $10 \mu \mathrm{g}, 10 \mathrm{pmol}$ setiap primer dan "pure taq DNA" (Promega) dengan total volume keseluruhannya 25 $\mu \mathrm{L}$. Siklus PCR yang digunakan dalam amplifikasi adalah satu siklus denaturasi pada suhu $95^{\circ} \mathrm{C}$ selama 2 menit. 35 siklus penggandaan yang terdiri atas $95^{\circ} \mathrm{C}$ selama 1 menit, $45^{\circ} \mathrm{C}$ selama 1 menit, dan $72^{\circ} \mathrm{C}$ selama 2,5 menit. Selanjutnya satu siklus terakhir pada suhu $72^{\circ} \mathrm{C}$ selama 10 menit.

Sekuense MtDNA yang didapat direstriksi dengan menggunakan endonuklease yaitu, Rsal, Ndell, Taql, dan Sacl sesuai dengan prosedur standar perusahaan. Hasil restriksi kemudian dipisahkan secara elektroforesis dengan menggunakan gel agarose $2 \%-3 \%$ dalam Tris-BoricEDTA (TBE) buffer dan diamati dengan illuminator (UV) serta dicetak gambarnya dengan polaroid.

\section{KERAGAMAN GENETIK KIMA (Hippopus hippopus)}

"Sekuens" Mt DNA Cytochrome 1 dari kima hasil PCR mempunyai panjang sekitar $750-1.300$ bp. Empat dari tujuh enzim restriksi yang digunakan untuk memotong sekuens tersebut (Rsal, Ndell, HaellI, dan Alul), mempunyai situs pemotongan. Polimorfisme pola pemotongan hanya didapatkan pada dua enzim restriksi yaitu Rsal dan Ndell. Pemotongan sekuens MtDNA Cytochrome B dengan menggunakan enzim Rsal, menghasilkan tiga jenis pola. Ketiga pola pemotongan tersebut antara lain, tipe 1 mempunyai 2 fragmen dengan panjang $300 \mathrm{bp}$ dan $450 \mathrm{bp}$, sedangkan tipe 2 dan 3 masing-masing dengan 3 fragmen dengan panjang 300 bp, 425 bp, dan 450 bp, serta 300 bp, 450 bp, dan 550 bp. Enzim Nde Il menghasilkan dua jenis pola pemotongan, yaitu tipe 1 mempunyai 2 fragmen dengan ukuran 600 bp dan 700 bp dan tipe 2 dengan 2 fragmen dengan ukuran 625 bp dan 650 bp. Salah satu contoh dari pola pemotongan oleh enzim restriksi tercantum pada Gambar 2. Ukuran sekuens M tDNA Cytochrome B ini lebih pendek 
dengan panjang sekuens daerah yang sama pada beberapa ikan laut seperti: kingfish, yellow tail, dan red sea bream (Nugroho, 2001).
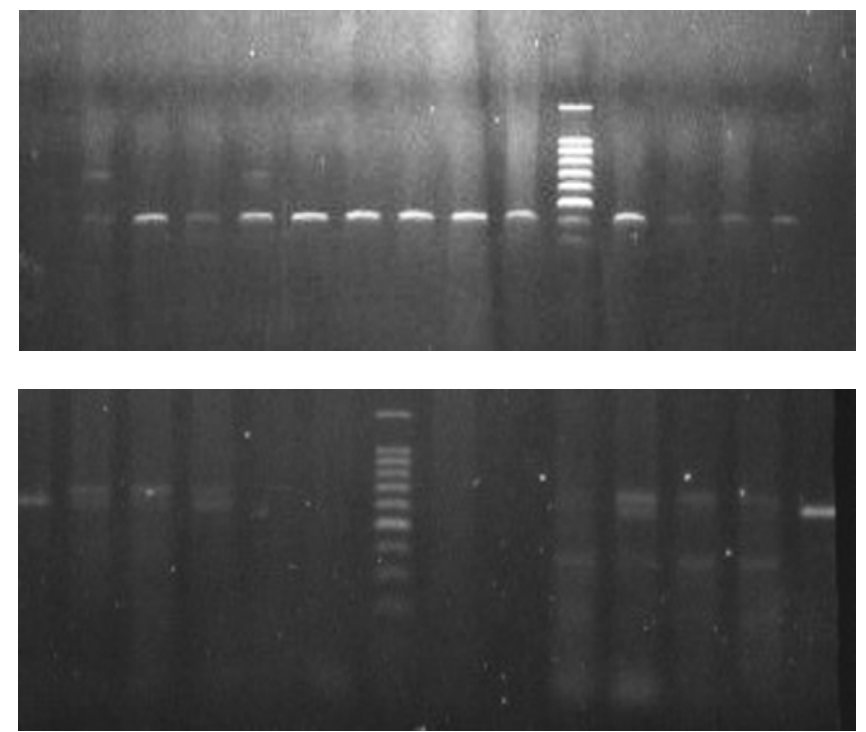

Gambar 2. Pola restriksi Cytochrome I dengan enzim Rsal (atas) dan Ndell (bawah)

Secara umum kima yang diteliti mempunyai tingkat keragaman yang rendah jika dibandingkan dengan organisme laut lainnya yaitu dengan nilai diversitas haplotype atau heterozigositas 0,023--0,073 (Tabel 1). Nilai ini lebih kecil dengan hasil yang diamati oleh RavagoGotanco et al. (2007) pada Tridacna crocea dengan menggunakan metode allozyme. Rendahnya keragaman genetik pada kima ini dimungkinkan karena kemampuan migrasi dari kima yang rendah pula sehingga kemungkinan terjadinya perkawinan antar populasi di alam jarang terjadi. Fenomena lain yang diduga penyebab rendahnya keragaman genetik kima di Indonesia adalah masih belum banyaknya usaha budidaya, sehingga peluang untuk terjadinya pertukaran dan perkawinan antar rasras kima juga kecil. Salah satu akibatnya adalah kemungkinan terjadinya silang balik atau cross over adalah kecil, sebaliknya peluang perkawinan dalam keluarga atau inbreeding sangat besar. Keadaan ini jika terjadi dalam jangka waktu yang lama akan mengurangi tingkat

Tabel 1. Keragaman genetik kima berdasarkan polymorfisme mtDNA Cytochrome I

\begin{tabular}{lcc}
\hline & P (Induk) & F1 (Anak) \\
\hline N-sample & 6 & 40 \\
N-allele & 7 & 12 \\
Heterozygositas & 0,023 & 0,073 \\
\hline
\end{tabular}

keragaman dari populasi tersebut, bahkan tidak menutup kemungkinan akan menjadi populasi yang homogen.

Secara umum, keragaman genetik anak kima hasil budidaya meningkat sekitar 0,050 jika dibandingkan dengan induknya. Besaran nilai variasi ini umumnya terjadi pada populasi hasil budidaya pada satu generasi tertentu dengan jumlah induk yang tertentu pula. Meningkatnya keragaman kima hasil pembenihan ini menunjukkan bahwa kemungkinan induk yang digunakan bukan berasal dari galur yang murni.

Keragaman genetik turunan pertama (F1) mempunyai nilai yang jauh lebih besar dibandingkan dengan induknya mengindikasikan bahwa tidak terjadi penurunan seperti yang umumnya terjadi pada hasil budidaya organisme lainnya. Fenomena ini dimungkinkan karena jumlah induk yang digunakan dalam pemijahan cukup besar sehingga dapat mengurangi laju inbreeding.

Secara statistik dengan menggunakan AM OVA (Analysis Molecular Variance) terdapat perbedaan genetik secara nyata antara populasi kima yang diuji $(P<0,05)$ berdasarkan situs pemotongannya. Hal yang sama juga tercermin dari nilai jarak genetik Nei (1972) di antara keduanya yang relatif kecil yaitu 0,016 . Indikasinya adalah bahwa populasi induk dan anaknya merupakan satu populasi yang sama. Informasi secara anatomi perlu dilakukan untuk melengkapi hasil pengamatan ini.

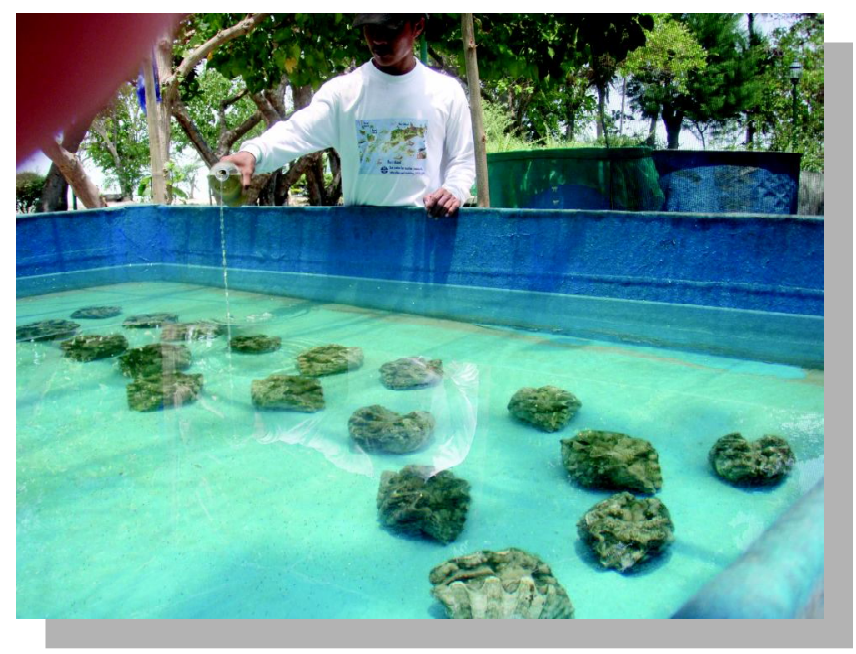

Gambar 3. Pembenihan kima

\section{KESIMPULAN}

Tidak terdapat perbedaan genetik yang nyata antara kima induk dengan F1-nya. Keragaman genetik pada F1 meningkat dibandingkan dengan induknya, yaitu 0,073 dan 0,023. Jarak genetik antar populasi yang diuji adalah sebesar 0,016. 


\section{DAFTAR PUSTAKA}

Ferguson, A.J., A.J. Taggart, P.A. Prodohl, O. McMeel, C. Thompson, C. Stone, P. McGinnity, and R.A. Hynes. 1995. The application of molecular markers to study and conservation of fish populations, with special refference to Salmo. Journal of Fish Biology. 47: 103-126.

Nei, M. 1972. Genetic distance between populations. American Nature. 106: 283--292.

Nugroho, E. 2001. Population genetic studies on the aquaculture fish in genus Seriola for their risk management. PhD Thesis. Tohoku University. 123 pp.

Pearson, R.G. 1977. Impact of foreign vessels poaching giant clams. Aust. Fish J. 36(7): 8--11.

Panggabean, L.M.G. 1987. The status of of tridacnid clam and its preliminary culture stock on Pari Islands. BIOTROP Spec. Publication. 30: 53--62.
Ravago-Gotanco, R.G., R.M. Magsino, and M.A. JuinioMenez. 2007. Influence of the North Equatorial Current on the population genetic structure of Tridacna crocea (Mollusca: Tridacnidae) along the eastern Philippine seaboard. Marine Ecology Progress Series. 336: 161--168.

Rosewater, J. 1965. The family oTridacnidae in the IndoPacific. Indo-Pacific Mollusca. 1: 347--396.

Rosewater, J. 1982. A new species of Hippopus hippopus (Bivalvia:Tridacnidae). Nautilus. 96: 3--6.

Wells, S.M., R.M. Pyle, and N.M. Collins. 1983. Invertebrate Red Data Book International for Conservation of Nature, Cambridge, U.K. 